\title{
Obituaries
}

Obituaries should be submitted by email to Laura Pacey at I.pacey@nature.com.

All submitted obituaries should be 350 words maximum in length (apart from obituaries for past presidents of the BDA where the length should be $700-800$ words).

Content of the obituary is down to the individual author, and the approval of the family should be given for the obituary prior

to submission to the $B D J$.

\section{GEORGE EDWARD HUNTLEY}

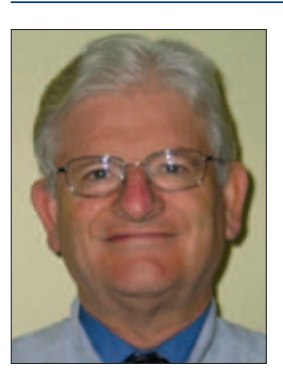

George Huntley, a dental surgeon on the Isle of Man, died peacefully at his home in Glentramman, Isle of Man on 16 April 2012 after a short illness. George was born on the island in 1942, where he attended King Williams College. George was a popular, conscientious pupil, always willing to help others. He qualified at the London Hospital in 1965.

After a short period as a House Officer in London, George undertook a VSO position in Malaya for two years, helping to set up the Flying Dental Service and visiting outlying villages under military escort.

George returned to the island in 1969 and started a practice in Ramsey with John Burns, a semi-retired dentist from Liverpool. During his career he built two dental practices, the second being at Grove Mount where he was joined by Peter Coombe, Rod Jones and others; and under George's forward-thinking and dedicated leadership, the practice became the largest in the Isle of Man, well-recognised for its excellence.

George married Rosemary in 1972; they have two daughters, Julia and Georgina, and five grandchildren, Grace, Emily, Alexander, Isabel and Barnaby. George loved family life and was a devoted husband, father and grandfather. They warmly entertained friends, enjoyed walking holidays in Italy and France, and travelled widely. George was a keen photographer, an active member of Rotary, with a special interest in organising international exchanges. He was awarded a Paul Harris Fellowship twice for his services.

George earned huge respect and affection from his patients, being gentle, empathetic and professional, often a friend and counsellor, whom they referred to as 'Uncle George'. He touched many peoples' lives, as evidenced by the large number of people who attended his funeral. After George retired, his patients used the expression 'life after George' in a fond way. Now, it really is life after George, but he is lovingly and specially remembered. I consider myself very fortunate to have been associated with George and his family.

Roger M. Godfrey

\section{DAVID J. DAINTY}

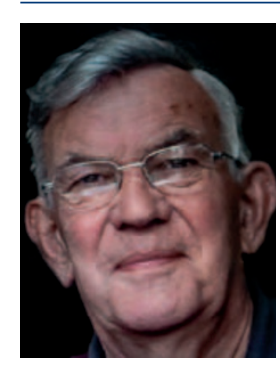

David Dainty was a committed general dental practitioner practising amongst likeminded colleagues who were prepared to offer 'out of hours' services to patients in need.

He was born in Letchworth, Hertfordshire moving with his parents to Stanford-le-Hope where he attended Palmers Boy's School in Grays. He pursued dental studies at the London Hospital Dental School where he qualified in 1963. Always a keen sportsman, he played football and water polo for his dental school and proudly boasted that he was an 'Old Londoner'.

After qualifying he practised as an assistant for a short while in Essex. Coming to Devonshire in 1964 he was welcomed into a Kingsbridge family practice where he quickly established himself with kindly demeanour. David remained in this practice, eventually becoming a partner, always pursuing postgraduate studies until his retirement as senior partner in 2005.

An active member of the BDA since qualifying, he joined the Plymouth Section and became Chairman 1976-1977. He became the second Editor of the Branch magazine Contact Point and was elected President of the Western Counties Branch in 1987. He was also on the editing board of Dental Update.

As a young man he joined Round Table and later the 41 Club. On the foundation of the Kingsbridge Estuary Rotary Club he was invited to join and worked in several offices. During their 25th year celebrations he was honoured to be elected as their President and awarded the accolade of a Paul Harris Fellowship for services to the Rotary Movement. Closer to home he was a governor of West Alvington primary school, a parish councillor and a stalwart of the Anglican Church, where he was joint treasurer.

David loved his golf and retirement gave him the opportunity to pursue this interest after a hard working life looking after his patients. He was diagnosed with pulmonary fibrosis two years ago.

West Alvington Parish Church was full to overflowing for David's funeral service. Colleagues, former patients and friends were standing along both side aisles. Those unable to gain access to the interior were able to participate through a pre-installed public address system outside.

He leaves his devoted wife Hilary after a happily married life of 49 years, three daughters and seven grandchildren to whom we extend our sincere sympathies.

Keith Millman MBE 